\title{
Basic Values and the Victim's State of Mind
}

\author{
Meir Dan-Cohen $\dagger$
}

The story of Sandy Kadish's professional life to date is very much the history of American criminal law in the second half of the twentieth century. The event that played a formative role in both was no doubt the drafting of the Model Penal Code early in this period. ${ }^{1}$ Headed by Kadish's great and greatly admired teacher, Herbert Wechsler, the project has been later depicted by Professor Kadish ${ }^{2}$ as the culmination of a series of codification efforts whose intellectual pedigree Kadish traces back to Bentham's utilitarianism. ${ }^{3}$ Not surprisingly, one dominant theme in Professor Kadish's work has been a reaction to this creed. One finds in his work an appreciation of the humainzing and rationalizing insight that a utilitarian perspective can bring to the law, coupled with a wise critical attitude that highlights the limitations of this perspective and seeks additional normative resources to supplement it. ${ }^{4}$ In this regard, Kadish's work echoes in the context of criminal law one of the dominant strands in the inoral philosophy of the era: a critical reexamination of utilitarianism and a deontological, for the inost part Kantian, response to it. This paper shares this general approach and is a step in the same enterprise. What I propose, for the most part, is a further developinent, perhaps refinement, in the normative landscape that emerges out of the deontological critique of utilitarianism. Although my proposal thus proceeds in a generally familiar vein, it is inade

Copyright $\odot 2000$ California Law Review, Inc. California Law Review, Incorporated (CLR) is a California nonprofit corporation. CLR and the authors are solely responsible for the content of their publications.

$\dagger \quad$ Milo Reese Robbins Professor of Legal Ethics, University of California, Berkeley, School of Law (Boalt Hall).

1. The Model Penal Code was produced over a period of 10 years, starting in 1952.

2. See Sanford H. Kadish, Codifiers of the Criminal Law: Wechsler's Predecessors, 78 Colum. L. REv. 1098 (1978).

3. Footprints of Benthamite utilitarianism are clearly visible in Herbert Wechsler, The Challenge of a Model Penal Code, 65 HARv. L. Rev. 1097 (1952); and Herbert Wechsler \& Jerome Michael, A Rationale of the Law of Homicide, 37 Colum. L. REv. 701, 1261 (1937).

4. This theme is probably most clearly evident in the following essays: Kadish, supra note 2; Sanford H. Kadish, Legal Norm and Discretion in the Police and Sentencing Processes, 75 HARV. L. REv. 904 (1962); and Sanford H. Kadish, Respect for Life and Regard for Rights in the Criminal Law, 64 Calif. L. Rev. 871 (1976). These essays are collected in Sanford H. Kadish, Blame and Punishment: Essays in the Criminal Law (1987). 
from a somewhat unusual vantage point. I look at the normative foundations of criminal law, at its basic organizing values, through the victim's eye, or, more precisely, through her mind's eye: What significance, if any, do the victim's mental states play in defining criminal liability? To what extent does the harmfulness or wrongfulness of an action depend on its relationship to the victim's psychology?

These questions are worth exploring for their own sake. We are all accustomed to the criminal law's sharp division between mens rea, said to comprise the subjective aspects of criminal liability, and the actus reus, which comprises the objective elements of crime. But this standard rendition of the doctrinal divide is inaccurate, since criminal offenses often involve a subjective factor other than the state of mind of the offender, namely, the victim's state of mind.

This factor does not fit comfortably into the dominant binary structure. If the offender is our reference point for drawing the subjective/objective line, then the victim's state of mind is indeed an objective factor, that is, it is realized in the world outside the offender's mind and, thus, is one of the external circumstances that form the actus reus. Although this classification is formally correct, there is an obvious incongruity in attaching the label "objective" to the victim's mental state in supposed contradistinction to the "subjectivity" of the offender's intentions. The result is to downplay or hide the fact that there is more to the subjective aspect of crime than what goes on in the offender's mind. In some offenses, such as larceny and rape, this fact is too salient to be ignored, since the victim's state of mind-lack of consent in these examplesappears explicitly in the definition of the offense. But what is less apparent, though no less true, is that the victim's state of mind is potentially relevant and can play a tacit role im many other crimes as well. Subjective elements raise obvious, and in the case of mens rea, widely recognized epistemological and evidentiary problems, so it is worth noting in a systematic fashion that such problems proliferate when an additional subjective component is taken into account. Important as these issues are, however, they do not provide the main impetus for this paper. My main motivation for drawing attention to the victim's state of mind is simply that it offers a relatively unoccupied and unfamiliar perspective from which to reexamine some fundamental issues concerning the normative basis of criminal hability.

\section{I \\ SOME PreLIMINARIES}

To draw attention to the sigmificance of the victim's state of mind is not to clain for it equal significance with the offender's. To begin with, though an offender is imvolved im every crime, not all crimes have a victim. 
So the issues I consider do not always arise. Even when a victim exists, the role played by her state of mind is quite different from that of the offender's. In parallel with the distinction between actus reus and mens rea, it is common to distinguish those elements of a criminal offense that determine its harmfulness or wrongfulness from those that define the offender's culpability. Whereas mens rea concerns the latter, the victim's state of mind belongs to the former; it helps determine an action's harmfulness or wrongfulness. How does it do so? In considering this question, it will help to distinguish, as we do in the case of mens rea, between the victim's cognitive attitudes, that is, knowledge or awareness of what transpired, and her conative ones, that is, her desire, approval, or consent.

Another notion that will prove a handy heuristic is that of a basic offense. We are used to thinking about criminal offenses in generic terms, say as "larceny," or "assault," or "speeding." But offenses are of course also discrete events that occur one at a time. The notion of basic offense pertains to such particular tokens of the generic offenses we define. A particular occurrence of an offense is a basic offense when that occurrence involves a setback to or a diminution in a basic value that is protected by the generic offense. A basic value is the normative point of origin, or the basic normative premise, in a chain of reasoning designed to provide a complete justification for having the prohibition in question. A test for a basic offense would be: would we have prevented this occurrence if we possessed a perfect technology of crime control, by which I mean the capacity, based on prescience and superior communication capabilities, to identify in advance and avert all and only those actions that would have resulted in an infringement of a basic value? (By analogy to the image of "the policeman at one's elbow," sometimes used to establish the voluntariness of allegedly coerced action, think here of "a legislator at one's elbow" who, on the basis of complete information, will prohibit particular actions when they are deemed deleterious.) Take traffic regulations, for example. Assume that their sole purpose is to prevent the loss of life, limb, and property that results from car accidents. (This ignores other likely goals, such as securing a smooth flow of traffic, which would complicate the analysis without altering it substantially.) Further suppose that preventing such losses provides all by itself a reason for the regulation of traffic. In this case, the basic traffic offenses are the ones that result in accidents involving one or another of the enumerated losses. With a perfect crime control technology at our disposal these would be the only traffic offenses we would care to prevent. For example, only those occurrences of speeding destined to result in harmful accidents would be of legal concern. Offenses that do not meet this criterion are secondary or derivative: They are prohibited solely because of imperfections in the available crime control technology and are justified only indirectly by the practical imperatives 
of preventing basic offenses. We forbid all speeding simply because we cannot distinguish in advance the harmful instances from the innocuous ones. The notion of a basic offense is a theoretically useful heuristic that helps clarify our basic values: the ultimate reasons for disapproving of a particular action and forbidding it. ${ }^{5}$

The question I want to raise concerning the victim's state of mind can be now further specified as follows: When, if ever, is the victim's knowledge or his lack of consent one of the conditions for the occurrence of a basic offense?

II

\section{UTILITY AND THE VICTIM'S EXPERIENCE}

To answer this question we must relate different values supposedly served by the criminal law to the victim's states of mind. But what values does the criminal law promote or defend? A natural place to begin is by focusimg on some paradigm offenses, such as assault, battery, and rape, and inquiring into their normative underpinmings. As I indicated at the outset, it is equally natural to look for an answer in some version of utilitarianism. What role would a utilitarian assign to the victim's knowledge and consent? With regard to knowledge, the answer, at least in broad outline, is quite straightforward. As formulated most bluntly by Bentham, the basic units of utilitarian value are individual pain and pleasure. ${ }^{6}$ The wrongfulness of such actions as assault, battery and the like essentially depends on their painfulness to the victims, where painfulness is to be understood in a suitably broad and inclusive sense. Utilitarianism subscribes, in other words, to an experiential theory of value; the reason for forbidding any behavior must point to the negative experiences it involves. The victim's state of mind in the form of an unpleasant experience brought about by the putatively criminal behavior seems accordingly an essential component in the case for criminalizing that behavior.

Although the victim must be aware of the unpleasant consequences of the offender's actions, he need not be aware of them as consequences of such actions. The knowledge that the pain was wrought by the offender's conduct, or indeed that human agency was involved at all, is relevant only insofar as such knowledge changes, and most likely auginents, the

5. For another view, compare the notion of ultimate value in JOSEPH RAZ, THE MORALITY OF FREEDOM 177-79, 200 (1986).

6. See Jeremy Bentham, The Principles of Morals and Legislation 1 (Prometheus Books 1988) (1789). Utilitarianism has been engaged ever since in an ongoing struggle against its hedonistic origins. Though I do not believe that a satisfactory, non-experiential alternative has been developed, the matter is highly contested. At any rate my comments are addressed to utilitarianism in its classical, Benthamite form. For good surveys and discussions of the arguments on this point, see JAMEs GrifFIN, Well-Being: Its Meaning, Measurement, and Moral Importance (1986); and L.W. Sumner, WELFARE, HAPPINESS, AND ETHICS (1996). 
unpleasantness of the experience. When does it? The basic idea is captured by the locution "adding insult to injury": If someone deliberately steps on my toes, not only my toes are hurt, but my feelings too. This piece of ordinary wisdom not only highlights the significance for criminal liability of the offender's intentions, but it also brings into the foreground the victim's state of mind: For his feelings to be hurt, it is not enough that the painful consequences of the offender's conduct be felt by the victim; he must also realize that the pain was brought about intentionally. ${ }^{\text {? }}$

It should also be observed that even within the utilitarian's experiential conception of value, an unpleasant experience is not strictly necessary in order to give rise to a basic offense. There is room within the felicific calculus for hypothetical or counterfactual experiences that could have materialized but did not. An offense can accordingly consist in blocking what would have been a positive, that is, pleasurable, experience, and thus may take place without the victim ever knowing about it: Unbeknownst to the victim, if it weren't for the offender's behavior, she would have been better off than she is.

With the exception of sucli counterfactuals, utilitarianism forges a tight conceptual link between harm and the victim's awareness of it. It assigns no similar significance, however, to the victim's conative attitudes, specifically to consent. For the most part, whether the victim approves of the offender's behavior or even desires it is only contingently related to its harmfulness and hence to the definition of the pertinent basic crinie. The fundanental question is always the saine: Did the putative offender's conduct diminish the victim's welfare in the relevant experiential sense ${ }^{8}$ Consent by itself plays no direct role in this inquiry. People's conative attitudes, in the form of preference or consent, are of course prominent in utilitarian thinking, supported by the assumption, sound though rebuttable, that people are generally the best judges of their own interests. But, it should be clear, this assumption, and hence the attitudes it ushers, is irrelevant to the present inquiry into the constituents of basic crimes. This inquiry is essentially conducted ex post, when all the information concerning the offender's conduct and its consequences is already in. The victini's erroneous antecedent assessment of the action's likely experiential effects is of no greater moinent at this point than any other faulty assessinent that may have preceded the action. Even so, consent or its absence can play an indirect role in shaping the unpleasant experience and in fixing

7. As Justice Holmes famously observed, "[e]ven a dog distinguishes between being stumbled over and being kicked." Oliver Wendell Holmes, The Common LAw 7 (1963). The point is augmented and elaborated in Benjamin B. Sendor, Crime as Communication: An Interpretive Theory of the Insanity Defense and the Mental Elements of Crime, 74 GEo. L.J. 1371 (1986).

8. This, of course, is only a necessary but not a sufficient condition for a negative ntilitarian assessment of the action; the suffering inflicted may have prevented greater suffering or may be outweighed by greater pleasure that the action brings about. 
its intensity. Here again the idea of an insult is relevant: The very fact that the offender's injurious acts were performed in derogation of the victim's wishes adds insult to the injury, whereas having chosen one's fate may make it easier to accept that fate and cope with it.

III

\section{AUTONOMY AND THE VICTIM's CONSENT}

Experiential welfare-individual welfare as refracted in people's psychic, subjective experience-no doubt plays a significant role in our public morality and in the criminal law. The fact that human suffering is involved is an important consideration behind the prohibition against the paradigm criminal offenses that $I$ have mentioned, such as assault, battery, and rape. But as a moment's reflection will disclose, the victim's suffering is not the only normative concern even in these paradigm offenses. Consider rape by deception. In People v. Minkowski, for example, the defendant, a gynecologist, had sexual intercourse with his patients on numerous occasions, unbeknownst to them. Although the physician was eventually found out, he had managed to conduct his nefarious affairs with his unsuspecting victims for quite some time. Yet all would agree, I suppose, that the patients had been raped even before their suspicions arose, and whether or not they would have ever discovered the truth. In my terminology, Minkowski's actions must be seen as basic crimes quite apart from any experiential effects on the victims. But if the putative victims are not even aware of, and hence do not suffer from, the defendant's conduct or its consequences, whence the disvalue of this conduct? What other value can buttress the judgment that a reprehensible rape occurred nonetheless?

It is easy of course to condemn the defendant's conduct in these circumstances and justify his punishment on various obvious rule-utilitarian grounds. But doing so would miss the point of the present inquiry. The crucial judgment I assume is that quite apart from any likely future ramifications of condoning Minkowski's conduct, his actions are reprehensible acts of rape by themselves and should be treated as such out of concern for the unsuspecting victims despite the fact that in their ignorance these victims are immune to any hurtful experience.

Having thus spelled out the challenge posed by Minkowski, the solution is not far off. We can recognize the challenge as a variation on a familiar theme: the deontological critique of consequeutialism in general and of utilitarianism in particular. For the most part this critique addresses the aggregative aspect of the utilitarian position and its willingness to trade off the interests of one individual for those of others. But the Minkowski case draws attention to a second, no less important, strand in the deon-

9. 23 Cal. Rptr. 92 (Ct. App. 1962). 
tological view: substituting another basic value for the utilitarian's notion of experiential welfare. What is that value? The most likely answer, though as I will point out momentarily not the only one, is autonomy. Although many different conceptions of autonomy exist, for present purposes a rough intuitive understanding of the core idea will do, namely, that people should be given control over the conduct of their own lives, or, which here amounts to the same, that people should have choices in matters that touch them and their lives. It is easy to see how the ideal of autonomy so understood helps account for the Minkowski case and support the judgment that a basic crime of rape has been committed even before the victims were aware of it. The simple point is that the very fact that the intercourse was nonconsensual is sufficient to incriminate it as a serious violation of the victims' autonomy. ${ }^{10}$

As the Minkowski case starkly demonstrates, viewing criminal law as promoting people's experiential welfare differs significantly from viewing it as protecting individual autonomy. Although protecting autonomy is often a sound strategy to advance welfare, mostly due to the assumption that people are by and large the best judges of their own interests, the two values do sometimes diverge and can come into conflict. There are two main areas in which such conflict comes to the fore: legal paternalism ${ }^{11}$ and the defense of consent. ${ }^{12}$ The underlying issue in both areas is essentially the same: Should the law concern itself directly with people's welfare or should it defer to their autonomy, even when it is believed that they have exercised their autonomy badly? The difference between the two areas is that paternalism comes into play when self-regarding behavior is concerned, whereas issues of consent arise in the case of other-regarding behavior. A unitary approach based on one value or the other is in principle possible im both areas. In the department of legal paternalism, a relentlessly autonomy-based approach would, for example, repeal safety belt laws, whereas in the consent department such an approach would allow gladiatorial combat if voluntary. Conversely, a welfare-based approach would likely ban smoking and severely restrict assisted suicide. What we have instead is an uncomfortable and shifting compromise between the two approaches, one that does not resolve the tension between them but rather reflects it.

10. See Carolyn M. Shafer \& Marilyn Frye, Rape and Respect, in FEMINISM AND PhilosophY 333 (Mary Vetterling-Braggin et al. eds., 1977), in which the authors diagnose the evil of rape as a matter of disrespect, and view respect as an attitude that relates to the victim's autonomy: "The morally appropriate attitude upon encountering another person is one of respect: recognition of its domain, and deference to its rightful power of consent." Id. at 339.

11. See generally PATERnalism (Rolf Sartorius ed., 1983).

12. See generally Wayne R. LaFave \& Austin W. ScotT, JR., CRiminal Law 477-80 (2d ed. 1986); J. H. Beale, Jr., Consent in the Criminal Law, 8 HARv. L. REv. 317 (1894-5). 


\section{IV DigNITY AND "STRICT VICTIMHOOD"}

\section{A. New Puzzles}

The two basic values we have so far considered, welfare and autonomy, treat the victim's state of mind very differently. A welfarist perspective makes the victim's awareness in the form of some negative experience a constituent of the basic crime; the victim's conative attitudes are only of secondary significance. The reverse is true of the autonomy perspective. Here the defining characteristic of the basic crime is incongruence with the victim's will; awareness on the victim's part is inessential. Further probing reveals, however, instances in which our considered judgment and extant legal practices cannot be plausibly explained in terms of either of these two values and in which, correspondingly, no essential role is played by the victim's state of mind. Such instances exhibit what, by analogy to the categories used in the mens rea department, we can call strict victimhood. Here are two examples.

The defendants in State $v$. Braxton ${ }^{13}$ were sentenced to thirty years imprisonment on charges of sexual misconduct but were given by the trial court the option to undergo surgical castration instead. They would have chosen castration had the appellate court not withdrawn that option. Why was this option withdrawn? Since the defendants preferred castration to incarceration, denying them this option seems to compromise rather than enhance their autonomy. But the court's paternalistic stance cannot be explained in terms of a concern for the defendants' welfare either: No one suggested that the defendants were mistaken in believing that diminished sexuality is preferable in this regard to thirty years in jail. What considerations, then, override the defendants' express wishes as well as their longterm welfare in this case ${ }^{14}$

In State v. Brown, ${ }^{15}$ the defendant habitually beat his wife when she drank alcohol, allegedly as part of an agreement to help her overcome her alcoholism. In convicting Brown the court rejected a defense of consent. How are we to assess the court's decision? To be sure, sound public policy arguments seem to support it: There is, for example, good reason to be suspicious in general of the genuineness of agreements such as the one here alleged. But such arguments are not pertinent to the narrow focus of my present inquiry. In ascertaining whether Brown committed a basic

13. 326 S.E.2d 410 (S.C. 1985). The eponymous defendant in this case is Brown; I refer to the case by the name of the second defendant (Braxton) to avoid confusion with the other case entitled State $v$. Brown I discuss infra at note 15 and accompanying text.

14. All the court says in explaining withholding the option of castration is that sueh punishment would be in violation of the state's constitutional prohibition against cruel and unusual punishment. See $i d$. at 412. No mention is made of the possible relevanee of the defendants' preference in the matter.

15. 364 A.2d 27 (N.J. Super. Ct. Law Div. 1976), aff d, 381 A.2d 1231 (N.J. Super. Ct. App. Div. 1977). 
crime we must focus exclusively on the case at hand, and ask what value, if any, has been infringed. Looking at this case in isolation and assuming that in this particular case Brown's wife did consent, we face a similar puzzle to the one in Braxton. Here, too, it is at least plausible to assume that by promising to cure her of her alcoholism, the violence served the victim's long-term welfare im the same way that a painful root canal treatment does; and as in the latter case, consent reconciles the "treatment" with the putative victim's autonomy.

Nonetheless, even with such reassurance that neither the wife's longterm welfare nor her autonomy were compromised by the beating, the feeling is likely to persist, I believe, that the beating is unacceptable and ought not to be condoned. ${ }^{16}$ Moreover, this judgment seems to rest on concern for the specific beaten wife, who, despite iny stipulations concerning her welfare and autonomy, remains the "victim" in this scenario, rather than on a unore general concern regarding the danger to other spouses that condoning such a practice inay present. ${ }^{17}$

To account for these cases it would be helpful to view them in a broader context. In discussing the Minkowski case, we have followed a dominant strand in the deontological response to utilitarianism: invoking autonomy as a substitute for, or supplement to, welfare as a basic liberal value. But as Braxton and Brown suggest, autonomy cannot always explain our intuitive objection to certain actions. To do so, the deontological approach itself must be expanded and refined. We can best diagnose the problem and outline a solution by performing a short detour into neighboring and familiar territory. The institution of slavery has long served in the liberal literature as a stock antiutilitarian example and as a demonstration of the merits of a deontological approach. But on closer inspection, slavery threatens to einbarrass the deontologist as much as the utilitarian. By revisiting the slavery conundrum we will be better able to assess the role of autonomy within the deontological perspective and see more clearly what elaboration of that perspective is needed to escape the embarrassments it potentially faces.

16. In denying the defense of consent, the court relies on three main arguments: that condoning the defendant's conduct would encourage future violence, see id. at 29-30; that the assault is a "breach of the peace," and not just a violation of the victim's rights, id. at 29; and that the right to life and security is inalienable, see id. Only the latter two arguments qualify Brown's conduct as a basic offense in my terminology. But why is an assault in the privacy of one's home a breach of the peace? What makes the right to security inalienable? And why isn't this right at play in boxing and other violent sports?

17. For a related discussion of puzzles to which victims' consent can give rise, see Leo KATZ, Ill-Gotten Gains: Evasion, Blackmall, Fraud, and Kindred Puzzles of the Law 145-57 (1996). 


\section{B. Slavery: A Detour}

One way in which slavery serves as a counterexample to utilitarianism is by exposing and targeting its aggregative aspect: As long as enough people are sufficiently benefited by slavery, the institution is justified on utilitarian grounds, no matter how wretched the slaves' lives turn out to be. Utilitarianism is here castigated for its willingness to sacrifice some people in order to benefit others. ${ }^{18}$ But slavery presents the utilitarian with an additional embarrassment, one more pertinent to our present discussion, in the form of the specter of the happy slave. Here we focus on a particular slave who, we are asked to imagine, is quite happy with his lot. Can we raise any objection to his enslavement on utilitarian grounds? ${ }^{19}$ This thought experiment highlights the utilitarian's impoverished conception of value. By limiting the normative inquiry to the slave's welfare, the utihtarian is bound to overlook the decisive moral factor in the slave's predicament. But what is the decisive factor? If the slave's welfare is not negatively affected, what would be the basis for protest? The most common and seemingly obvious answer is usually given using the idiom of freedom or autonomy. It is the utilitarian's blindness to such values that is responsible for her inability to appreciate the moral unacceptability of the happy slave's situation.

How precisely does slavery relate to autonomy? Two different moments should be distinguished. The first concerns the circumstances of enslavement. We ordinarily assume that enslavement itself is involuntary, foisted on the slave through brute force. But what about consensual enslavement? ${ }^{20}$ To avoid the repugnant conclusion that voluntary enslavement is morally sound, the liberal must maintain that through this exercise of one's autonomy one sacrifices more autonomy than one gains. I am not sure how convincing this argument is in its own terms. After all, every contract involves some restriction on freedom of choice, and yet, since the restriction is self-imposed, contracts are generally perceived as an embodiment rather than as a denial of autonomy. Should each contract be made vulnerable to an assessment of its overall effects on the parties' autonomy?

Be this as it may, the entire onus of this response to the problem of voluntary enslavement rests on the second moment in the relation of autonomy to slavery: Whether or not the slave agreed to the enslavement,

18. See, e.g., R. M. Hare, What Is Wrong with Slavery, 8 Philosophy \& Public Affairs 103 (1979).

19. See the preface to Don Herzog, Happy Slaves: A Critique of Consent Theory (1989), where the author raises some of these issues but eschews the use of the kinds of thought experiments 1 indulge in favor of a historical study of the idea of consent in liberal theory.

20. The locus classicus of this discussion is John Stuart Mrld, On Liberty, in Utilitarianism, Liberty, AND RePRESENTATIVE Government 158 (E.P. Dutton \& Co. 1951). For a critical commentary of Mill's argument, see C. L. TEN, MrLL ON LiberTy 117-23 (1980). 
the ongoing regime under which he lives is assumed to consist in a severe limitation of his freedom of choice. But here too we inust tread carefully. Is it really necessary that to be a slave one's choices must be severely curtailed? It should first be noticed that the questiou must be understood as inviting a relative or comparative judgment: Everyone's options are limited, so the slave's situation could be distinguished in this regard only if his options were more restricted than those of nonslaves. But that need not be the case. We can easily imagine a nonslave whose options are in fact fewer, say due to severe handicap, than those of a slave whose master, out of benevolence or enlightened self-interest, gives him considerable free rein. It may perhaps seem that the slave's predicament can still be understood in terms of limitations on choice if we focus on the reliability of those options rather than ou their number; the nonslave's options, even if more numerous, are precarious since they can be withdrawn at any time at the master's whim.

But I do not think that such an account will do. First, it does not seem plausible to focus here exclusively on the reliability of having the options available without regard to their range and significance. If reliability is to be taken into account, it would more likely be part of a calculation of something like the expected value of one's overall choice set, in which the number and significance of options is weighted by the likelihood that they will not be withdrawn. But if this is the more plausible measure of one's freedom, theu we can easily make compensating adjustments in the scenario we imagine, such that the larger number of options available to the slave will be made to offset the greater reliability of the fewer options the handicapped nonslave enjoys. Secondly, the slave's options need not in fact be less secure than the nonslave's. We can posit a master whose firm, perhaps obsessive, character makes it all but impossible for her to depart from her benevolent policy toward her slaves, while subjecting the nonslave to a progressive congenital disease likely to bring all options to a terminal end at any time.

If autonomy is to be assessed, plausibly, in light of the actual range of options available, and if, also plausibly, the assessment must be comparative, then the foregoing considerations lead us to the specter of the free slave. Just as the happy slave demonstrates that welfare is not the only value in this context, so does the free slave show that neither is autonomy. Indeed, since we can combiue both scenarios to create the slave who is both happy and free, it seems that a composite normative theory that espouses both welfare and autonomy must be incomplete too.

But isn't a "free slave," on which this line of reasoning rests, a glaring oxymoron? Isn't loss of autonomy the very essence of slavery? The answer to these questions depends on the distinction between de facto and de jure autonomy. My examples, if convincing, demonstrate that de facto 
autonomy or its curtailment is not essentially linked to slavery, leaving however the possibility that de jure autonomy is so linked. Someone who enjoys de facto freedom of choice may yet be enslaved de jure. This possibility removes the oxymoronic appearance of the "free slave" figure we have imagined, but it does so by raising a different puzzle: If two people can enjoy in fact the same level of welfare and exercise the same degree of choice, yet one of them be a slave and the other not, wherein does the evil of slavery lie? Why is the mere de jure distinction important?

At this point the reader may simply wish to deny the premise of these questions. Since our imaginary slave is no worse off than his free counterpart, there is really no need for us to deplore his "enslavement." What makes slavery in general a heinous institution, the objection continues, is precisely the fact that real world slaves are in fact deprived of both welfare and autonomy to a shocking degree. Stipulate away these incidents, and you have removed those features that make slavery the paradigm of injustice. I think that this objection is umsconceived. We view slavery as a paradigm of injustice precisely because its injustice is necessary or analytical rather than contingent and empirical. To describe someone as a slave is ipso facto to view him as the victim of injustice, rather than to invite an mvestigation into the actual circumstances of his life. Why?

\section{Dignity and Respect}

The answer I think is quite obvious though its full import is not always clearly perceived. What remains evil about slavery even in the case of the slave who is de facto free and content is the affront to human dignity: Slavery is the paradigm of injustice because by its very terms it denies people's equal moral worth and thus treats them with disrespect.

Dignity, and the related ideas of equal human worth and respect, are all familiar constituents of the deontological perspective, and my aim here is not to explore them much further. ${ }^{21}$ I want only to point out two aspects of dignity and its related ideas that are directly relevant to my inquiry. The first may be referred to as the independence of dignity. Inspired by Kant, the deontological tradition often tends to treat dignity as interchangeable or convergent with autonomy. It is, for example, often assumed that the respect for persons that their dignity demands is a matter of deferring to their autonomy. It should be remembered, however, that the Kantian warrant for such a close link between dignity and autonomy extends only to Kant's rather narrow and quite idiosyncratic conception of moral

21. The most influential philosophical source of modern discussions of dignity is doubtlessly Kant. See, e.g., Immanuel Kant, Groundwork of THE Metaphysic of Morals (H. J. Paton trans., 1964). For a commentary that stresses the role of dignity in Kant's tbought, see THOMAs E. HILl, JR, Dignity AND PRactical REason In Kant's MoRAL TheORY (1992). There is a rapidly growing literature on dignity as a legal value. Some important essays are collected in THE CONSTITUTION of Rights: Human Dignity and American Values (Michael Meyer \& W. A. Parent eds., 1992). 
autonomy. ${ }^{22}$ When it comes to personal autonomy, more broadly and loosely conceived, no such Kantian warrant exists; ${ }^{23}$ and as my discussion of slavery reveals, dignity is quite independent of such personal autonomy and may even conflict with it: One may live a life in which a sufficient range of choices is available, and yet be stripped of one's dignity ${ }^{24}$ How?

The second aspect of dignity that I wish to highlight provides a general answer to this question. Dignity is an expressive value demanding that people's behavior, physical and verbal, convey a certain attitude to other people, namely an attitude of respect. There are many ways in which respect can be conveyed and, correspondingly, many ways in which it can be withheld. But the main point here is that whether an action is consonant with dignity is at bottonı a matter of that action's meaning. ${ }^{25}$ How does such meaning accrue?

There are two answers to this question, and the case of slavery illustrates them both. First, an action (or in this case an institution) may offend people through its overt, explicit content. The best example of such a way of conveying disrespect is offensive speech, such as hate speech: In its most blatant and straightforward form such speech simply articulates the denial of its object's humanity and moral worth. Slavery belongs to that category inasmuch as fully articulating the meaning of this institution would involve such an explicit denial of the slave's dignity. But the disrespectful meaning of an action may also be conventional. The convention can be an arbitrary one, as is the case with many insulting gestures. But more likely the conventional meaning attaches to an action by virtue of certain empirical characteristics and consequences it typically has. Following Kant, we can say that the essence of disrespect is a failure to appreciate a person as a being whose value is independent of anyone or anything else, and who should therefore be treated as an end and not just as a ineans. Exploiting a person for one's own ends by inflicting on him harm

22. This, roughly, is the capacity all human beings are assumed to possess for moral selflegislation, and it includes the propensity to act on moral grounds. See generally KANT, supra note 21 .

23. The distinction between personal and moral autonomy is drawn along similar lines in RAz, supra note 5.

24. On the independence of dignity from the value of choice, see Robert E. Goodin, The Political Theories of Choice and Dignity, 18 AM. PHIL. Q. 91 (1981). On the independence of dignity from consent, see R. George Wright, Consenting Adults: The Problem of Enhancing Human Dignity Non-coercively, 75 B.U. L. REV 1397 (1995).

25. A considerable legal-philosophical literature has grown in recent years discussing some or all of the four interrelated notions mentioned in this paragraph: dignity, expressive value, respect, and meaning. For some salient examples, see generally RICHARD ABEL, SPEAKING RESPECT, RESPECTING Speech (1998); Elizabeth Anderson, Value in Ethics and Economics 17-43 (1993); Anita Bernstein, Treating Sexual Harassment with Respect, 111 HARv. L. REv. 445 (1997); Lawrence Lessig, The Regulation of Social Meaning, 62 U. CHI. L. REv. 943 (1995); Richard H. Pildes \& Ehzabeth S. Anderson, Slinging Arrows at Democracy: Social Choice Theory, Value Pluralism, and Democratic Politics, 90 Colum. L. Rev. 2121 (1990); Cass R. Sunstein, The Expressive Function of Law, 144 U. PA. L. Rev. 2021 (1996). 
or suffering with disregard for his own needs, interests, and desires is the clearest violation of this imperative. Now ordinarily slavery does just that and is, accordingly, an abomination to the slaves' dignity. Given this record, it is not surprising that slavery should be associated in our minds with indignity. ${ }^{26} \mathrm{My}$ present point however is that although the association has an empirical basis, it need not be limited to those instances in which the empirical conditions obtain. The meaning that attaches to slavery as an insult to dignity is retained even in the situation we imagined, in which the typical derogatory effects on the slave's welfare and autonomy are stipulated away.

It should also be clear now why dignity relates to the victim's state of mind differently than either welfare or autonomy. Both latter values are defined in terms of, and hence bear an essential relationship to, aspects of the mental life of those to whom those values apply. Consequently, to count as a breach of these values an action must stand in a certain relation to the putative victim's psyche; roughly, it must cause her suffering in the one case or be unwelcome to her in the other. But dignity is a matter of a person's equal moral worth, and its violation consists in denying that worth. Neither the value nor its violation engage the victim's state of mind in the way that both welfare and autonomy do. Though the point, I think, is plain enough, it is easy to miss for the following reason. People generally care about their dignity, and expressions of disrespect are painful to them. We may be tempted, therefore, to focus on this pain and view it as the ground for criticizing disrespect and as the sine qua non of its immorality. But such a view reduces disrespect to its utilitarian (negative) value, as just another source of unhappiness or pain, thus eliminating dignity as an independent moraI value altogether. If we do embrace dignity as an independent moral value, as I have tried to demonstrate we implicitly do, we should be perturbed by its violations even if the person concerned did not care about his dignity and hence did not suffer at all from the insult. By the same token, expressions of disrespect retain their negative moral value even if their targets are spared any hurt feelings because they remain unaware of these expressions. ${ }^{27}$

26. I take it that conceiving of a person as just a means, thus denying his or her equal moral worth, is the essence of slavery. This is why I see the connection between slavery and dignity in the Kantian sense as analytic. This, however, does not mean that there cannot be borderline arrangements whose classification as slavery may be contested. The arrangements imagined by Professor Greenawalt may well belong in this category. See Kent Greenawalt, Dignity and Victimhood, 88 CALIF. L. REv. 779, 787-788 (2000).

27. Describing the unaware target of disrespect as its victim may raise some doubts, however. Though not much depends on the preferrcd locution, an analogy will help allay these doubts. Think of the hapless teacher, who is the object of massive displays of mockery and ridicule by his students each time he turns his back to the class. I do not think that we would revise our pcrception of this teacher as "hapless," and hence as the victim of those displays, even if it turncd out that he never found out about the goings on. Indeed, our reaction to such obliviousness is liable to be mixed. Together with some 


\section{Dignity and Social Meaning: Solving the Puzzles}

I said earlier that a discussion of slavery will leelp solve the normative puzzles posed by the cases we have considered, and I liope it is now clear what the solution is. Slavery provides us with a paradigm of dignitary harm: harm that consists in demeaning or humiliating a person by denying his or her equal moral worth. ${ }^{28}$ Such manifestations of disrespect greatly vary in their significance, ranging from the trivial to the devastating. But they are all a matter of the meanings that certain actions, institutions, and expressions carry. The key to our cases accordingly lies in the social meaning that the actions and practices involved carry as expressions of disrespect for their targets. To understand these cases we must therefore attend more closely to the social meanings involved. ${ }^{29}$

The central feature of both Braxton and Brown that must play a central role in any account is physical violence. Why is violence objectionable? As we saw, the two inost obvious replies-that violence diminishes its victims' welfare and that it compromises their autonomy-are not available to us here, since the physical intrusions we consider involve neither. If any of these physical intrusions is to be condemned, a different ground for decrying violence must be found. The idea of dignity provides such a ground. But how can physical violence be linked to dignity quite apart from considerations of welfare and autonomy?

Our discussion of slavery provides the general outline of an answer. The fact that physical violence does ordinarily severely hinder both welfare and autonomy is reason enough to render it a clear and blatant manifestation of disrespect. But as we saw in the case of the free and happy slave, the expressive meaning of violence can outrun the reasons for ascribing that meaning to it. Expressive significance is not usually attached to

relief that the teacher's feelings were spared, it may also be felt that his blithely interacting with his students in ignorance of their misconduct compounds the insult and in that sense augments the injury. This footnote and the accompanying paragraph in the text were added to the original version in response to Professor's Greenawalt's 'resist[ance to] the claim that the victim's mental state matters less for a basic offense to dignity than for a basic offense to welfare or autonomy," id. at 786 , in the hope that they may somewhat soften the resistance.

28. Dignitary harms have been widely recognized, mainly in tort law and in constitutional law, though the prevailing tendency, I believe, is to assimilate them to a species of psychological harm. But as I've argued in the preceding Part, the moral significance of the respect owed to persons, and correspondingly the moral significance of expressions of disrespect, transcend the attitudes and experiences of the persons concerned. See, e.g., W. PAge KeEton ET AL., Prosser AND KEETON ON THE LAW OF TORTS § 111, at 778 (5th ed. 1984); Richard H. Pildes \& Richard G. Niemi, Expressive Harns, "Bizarre Districts," and Voting Rights: Evaluating Election-District Appearances after Shaw v. Reno, 92 Mich. L. REv. 483, 506-13 (1993); Robert C. Post, The Social Foundations of Defamation Law: Reputation and the Constitution, 74 CALIF. L. REv. 691 (1986). For a view of insult to dignity as a central aspect of all instances of wronging people and as relevant to our understanding of the role of punishment, see JefFrie G. Murphy \& Jean Hampton, Forgiveness and Mercy 43-53 (1988).

29. For related discussions of the legal significance of social meanings see, in addition to the sources cited supra in note 25, the essays in the recent Symposium, Social Norms, Social Meaning, and the Economic Analysis of Law, 27 J. LEGAL STUd. 537 (1998). 
actions arbitrarily or at random but for a reason; still the connection between the reason for ascribing to an action-type its symbolic significance and the tokens of that action need not be tight. Once an action-type has acquired a symbolic significance by virtue of the disrespect it typically displays, its tokens will possess that significance and communicate the same content even if the reason does not apply to them. Think, by analogy, of onomatopoetic words such as buzzer or swish. Such words do not denote what they do by virtue of the resemblance in sound, nor is their extension limited by such resemblance. Rather, denotation and extension are a matter of the words' conventional meaning, even though that meaning accrued to them in the first place due to their phonetic similarity at least to some of the sounds they came to denote. The relative independence of the expressive component of disrespect I described, and the linguistic analogy $I$ just drew, lead to the following conclusion. As long as certain actions are generally considered to express disrespect, one cannot entirely escape their meaming while knowingly engaging in them, no matter what one's motivations and intentions are. One does not have any more control over the meaning of one's violent behavior than Humpty Dumpty had over the use of words. ${ }^{30}$

These observations explain our judgment that the castration proposed in Braxton and the beating inflicted in Brown involve an affront to the subjects' dignity despite their agreement and enhanced welfare: When it comes to the expressive meaning of these actions, the typical case of violence casts its shadow over the exceptional. But this explanation is incomplete. A further question remains to be answered: How widely is that shadow cast? To appreciate the urgency of this question, consider some analogous situations to these two cases. The same surgical castration proposed in Braxton could be performed as part of some medical treatment or a sex-change operation. No one, I assume, would then impugn the operation as involving the slightest insult to the patient's dignity, nor indeed would it be linguistically appropriate to refer to the patient as the "victim" of such a procedure. But what distinguishes these medical procedures from the Braxton case? After all, the redeeming features of castration in these instances are that it advances the patient's welfare and is done with his consent. But if these factors are not sufficient to remove the stain of indignity in Braxton, why do they seem to suffice in the medical situation? Why do the negative connotations of physical mutilation not cast their shadow over the meaning that certain medical procedures have? A similar question arises with regard to the Brown case as well. Here the most

30. “'When I use a word,' Humpty Dumpty said, in rather a scornful tone, 'it means just what I choose it to mean -- neither more nor less." Lewis Carrol., Through THE Looking-Glass 131 (American edition 1977). On variations in the social meaning of violence, see Dov Cohen \& Joe Vandello, Meanings of Violence, 27 J. LEGAL STUD. 567 (1998). 
suitable comparison seems to be to competitive sports, specifically wrestling and boxing, in which the level of permissible violence far exceeds the level, if any, that would be tolerable in a Brown-type scenario. Why, again, does the nasty record of the typical case of violence define the meaning of the beating in Brown, but not that of, say, pugilistic violence? ? $^{31}$

The answer in both instances is quite straightforward. How far the shadow of a typical case will reach in defining the meaning of an atypical one depends in the first place on the way we conceptualize, categorize, and individuate the relevant social practices. The difference between the Brown case and boxing is first and foremost a result of the generic distinction we recognize between wife-beating and boxing. A "benign" case of wifebeating is still a case of wife-beating, and it draws its offensive meaning from the typical, nasty cases. But that meaning does not carry over to what we recognize and label as "boxing." Moreover, since within boxing violence is not denieaning to the participants, no disrespect will be conveyed by a boxer's punches even if the individual boxer holds the opponent below contempt and harbors the most degrading attitude toward him. Similarly, the crucial distinction in the Braxton case is between the practice of criminal punishment and that of medical treatment. The meaning we attach to the sane inedical procedure-castration in this case-will radically differ depending on which of these practices provides the interpretive teniplate. The negative connotations with regard to human dignity of physical mutilation extend to even such unusual punitive circumstances as those presented by Braxton, but they do not extend to the very different practice of medical treatinent.

There is, however, a second determinant of meaning that delimits the projection of the ineaning of soine actions and expressions onto others. Meanings are, in general, language-specific. Ordinarily, when we divine the meaning of a symbol, we must know what language the symbol is part of. When the question whether an action conveys disrespect toward its objects arises, implicit in this question is a determination of the relevant linguistic community within which this question of meaning arises and ought to be resolved. This question can often be safely ignored, because it is tacitly and unproblematically answered: There is just a single candidate language and community shared by all participants in the event. But occasionally this will not be so; in such a case, the issue of the relevant linguistic community must be explicitly addressed, and the choice required 1nay be difficult and controversial. I will not try to explore here in general terms the nature of the difficulties and controversies that are likely to

31. Although the court recognizes that the participants' consent is a defense in the case of sports such as football, boxing, or wrestling, see State v. Brown, 364 A.2d 27, 30 (N.J. Super. Ct. Law Div. 1976), it gives no convincing explanation as to what distinguishes these sports froun the instant case. 
ensue. ${ }^{32}$ Instead I will limit myself to just one example that will illustrate the present point and demonstrate how sensitivity to variations in linguistic community may bear on assessing a violent action's dignitary implications. My example concerns sadomasochism, ${ }^{33}$ and it may be best approached through a well-known case. The defendant in People $v$. Samuel ${ }^{34}$ was charged and convicted on the basis of videotapes depicting him beating another person in the context of a sadomasochistic encounter. This case shares the crucial features of other situations we have considered: physical violence that comports with the putative victim's will and overall wellbeing. Which of the various cases in this category does Samuels most closely resemble?

One close analogy that comes naturally to mind is to boxing. In both cases violence is used within an established and familiar practice, marked by the participants' consent and consistent with their welfare. No disrespect attaches to the use of violence within either practice. According to my earlier analysis, these facts shield the acts of violence in either case from the meaning that would ordinarily attach to an act of violence as such. On this view of the matter, to recogmize a violent action as an instance of sadomasochism is ipso facto to exempt it from its ordinary nefarious meaning. This seems to me an utterly plausible way of seeing the matter, but I suspect, and at any rate will assume, that this was not how the judges who convicted Samuels saw it. On this suspicion or assumption, what struck the judges' eyes as they watched the incriminating film was not at all akin to a boxing match. ${ }^{35}$ They were horrified instead by the sheer brutality of the spectacle. We need not suppose that the judges must have failed to appreciate the nature of the act as consensual and as sexually gratifying. But the analogy that occurred to them might have been a different one. They may have considered the situation as resembling more closely the Brown case. In other words, the recognition that gratifying a person's sexual desires even through violence need not be accompanied by an attitude of disrespect would not by itself undo the indignity of a sadomasochistic act in the absence of a recognized social practice that exempted this act from the meaning that attaches to violence in general. And unlike boxing, we can conjecture or assume, within the judges' social

32. Consider, for example, the idea that law often involves "translation" among different linguistic communities. These can be diachronic, as is the case in constitutional interpretation. See, e.g., Lawrence Lessig, Fidelity and Constraint 65 FordHAM L. REv. 1365 (1997). Or they can be synchronic, coexistent subcommunities within a larger society. See, e.g., JAMES BoYD WhITE, JuSTICE as Translation: An Essay in Cultural and Legal Criticism (1990).

33. See generally Brian Bix, Consent, Sado-Masochism and the English Common Law, 17 QuINNIPIAC L. REv. 157 (1997) (criticizing a recent decision by the House of Lords upholding criminal convictions related to consensual sadomasochistic behavior).

34. 58 Cal. Rptr. 439 (Cal. Ct. App. 1967).

35. The Samuels court alludes to sports such as football, boxing and wrestling, id. at 447 , but offers no ground for distinguishing them from the case at hand. 
milieu sadomasochism was not a recognized practice that would have reinterpreted for them the meaning of the acts they watched. However, and this is my present point, even if this reconstruction of the judges' mind-set is accepted, convicting Samuels may seem precipitate. The judges ought to take account of the fact that a sadonnasochistic community exists, and that within it the violence depicted in the incriminating film carries a distinct and well-understood meaning. Acquitting Samuels could, accordingly, be an expression of the court's deference to a community other than its own and to a meaning the court does not share.

\section{CONCLUSTON}

Our investigation into the moral and legal significance of the victim's state of mind imitially bore expected and familiar fruits. As we saw, the utilitarian tradition highlights the sigmificance of a person's experiences, whereas deontology stresses the will. In both cases moral concern for an individual resolves ultimately into a concern for effects, actual or counterfactual, within that individual's mental space. But further inquiry revealed that welfare and autonomy, even when broadly understood, cannot by themselves cover the pertinent normative terrain and that correspondingly, our moral concern exceeds the bounds of a person's psyche. A person can be the victim of, or can be harmed or negatively affected by, actions and events that occur entirely outside her mental space. To account for the cases that we have encountered in this category, we invoked the idea of dignity, insisting on the independence of this idea from the other values we have considered and highlighting the expressive and, hence, conventional aspect of dignity.

Many questions of course remain, but one seems particularly urgent. It concerns the nature of dignity and its claim on us. At least in broad outline, the content and the normative appeal of welfare and autonomy seem intuitively clear. But when dignity is divorced from such concerns, it may appear ephemeral or even empty: Why should we care about it? To adequately address this question would require a full-fledged theory of dignity, which it has not been my aim to provide. My goal has only been to demonstrate that close attention to some legal cases and the intuitive moral judgnients they incite reveals a need for such a theory. Still, a brief and tentative comment may be ventured.

Welfare and autonomy tend to appear as more fundamental or substantial values than dignity only as long as we focus on the first person point of view. From this perspective it may seem sensible to desire, and in this sense value, one's own welfare as well as the ability to control one's own life. When separated from these vital concerns, one's own dignity may indeed be of lesser moment. But this point of view does not provide us with the distinctive moral perspective. Here the central question 
concerns the treatment of others: What makes your striving for a better and sovereign existence my busimess? Why should I take your welfare and autonomy into account? Once we assume the distinctly moral, third person point of view, welfare and autonomy lose their obvious appeal and their driving force, and instead some other normative engine, such as dignity, is called for and indeed takes precedence. On one, broadly Kantian, account, my moral attitude simply consists in my acknowledging your own distinctive value and in my disposition to behave in a way that comports with this acknowledgment. According to this view of the matter, to make a moral claim on me, considerations that grow out of your welfare and autonomy must be first underwritten by your equal moral worth. Far from being derived from these other values, dignity is in this sense prior to them and more fundamental. 